\title{
ANTIMICROBIAL ACTIVITY OF SYZYGIUM CUMINI (MYRTACEAE) LEAVES EXTRACT
}

\author{
Guilherme Ferreira de Oliveira ${ }^{1}$; Niege Araçari Jacometti Cardoso Furtado ${ }^{1}$; \\ Ademar Alves da Silva Filho ${ }^{1}$; Carlos Henrique Gomes Martins ${ }^{1}$; Jairo Kenupp Bastos ${ }^{2}$; \\ Wilson Roberto Cunha ${ }^{1}$; Márcio Luís de Andrade e Silva ${ }^{1 *}$
}

${ }^{1}$ Núcleo de Pesquisa em Ciências Exatas e Tecnológicas, Universidade de Franca, Franca, SP, Brasil; ${ }^{2}$ Faculdade de Ciências Farmacêuticas de Ribeirão Preto, Universidade de São Paulo, Ribeirão Preto, SP , Brasil

Submitted: August 28, 2006; Returned to authors for corrections: March 05, 2007; Approved: March 19, 2007.

\begin{abstract}
The antimicrobial activity of Syzygium cumini leaves extract, known as "jambolão", was evaluated. The crude hydroalcoholic extract was active against Candida krusei (inhibition zone of $14.7 \pm 0.3 \mathrm{~mm}$ and MIC $=70 \mu \mathrm{g} /$ $\mathrm{mL}$ ), and against multi-resistant strains of Pseudomonas aeruginosa, Klebsiella pneumoniae and Staphylococcus aureus.
\end{abstract}

Key words: Antimicrobial activity, disk diffusion method, microdilution broth method, multi-resistant strains, Syzygium cumini.

Syzygium cumini (L.) Skeels (synonym Eugenia jambolana), popularly known as "jambolão", belonging to Myrtaceae family is one of the most commonly medicinal plants used to treat diabetes mellitus in Brazil (17). Different parts of this plant, such as seeds, bark, fruit, and leaves have been used in traditional medicine as a remedy for diabetes mellitus in many countries $(14,18)$. The leaves are also used to strengthen the teeth and gums, to treat leucorrhoea, stomachalgia, fever, gastropathy, strangury, dermopathy (21), constipation, and to inhibit blood discharges in the faeces (2). The folkloric use of this species to treat infectious diseases stimulated the investigation of the antimicrobial activity of the hydroalcoholic extract from Syzygium cumini leaves against standard and multidrug resistant Gram-positive and Gram negative human pathogenic bacteria, as well as against yeasts.

The authenticated plant material was provided by Bom Chá Comercial LTDA, São Paulo, SP, Brazil. Powdered air-dried leaves were exhaustively extracted with aqueous $96 \%$ ethanol at room temperature by maceration for 30 days. The extract was filtered and concentrated under reduced pressure to obtain the crude hydroalcoholic extract.

Two yeasts (Candida albicans ATCC 10231, Candida krusei ATCC 6258) and seven bacteria (Enterococcus faecalis ATCC
19433, Escherichia coli ATCC 14948, Kocuria rhizophila ATCC 9341, Neisseria gonorrhoeae ATCC 49226, Pseudomonas aeruginosa ATCC 27853, Shigella flexneri ATCC 12022, Staphylococcus aureus ATCC 25923) and three multi-resistant bacterial strains (Klebsiella pneumoniae and Pseudomonas aeruginosa isolated from uroculture, and Staphylococcus aureus isolated from hemoculture, resistant to commonly used antimicrobials, as well as sensible to Aztreonam, polymyxin B and vancomycin, respectively) were used to evaluate the antimicrobial activity of Syzygium cumini leaves hydroalcoholic extract.

The agar disc diffusion method (12) was used to evaluate the antimicrobial activity by measuring the inhibition zone against the test microorganisms. Petri dishes were prepared with a base layer of Mueller Hinton agar. At twenty-four hours culture of selected bacteria/yeasts was mixed with physiological saline solution and the turbidity was corrected by adding sterile physiological saline until a MacFarland turbidity standard of $0.5\left(10^{8} \mathrm{CFU} / \mathrm{mL}\right)$. Afterwards, a top layer of Mueller Hinton agar inoculated with $0.2 \%$ microbial suspension was poured over the Petri dishes. Bacto GC Medium Base was used for Neisseria gonorrhoeae. Sterile filter discs (6 $\mathrm{mm}$ in diameter) were impregnated with $16 \mu \mathrm{L}$ of plant extract $(100 \mathrm{mg} / \mathrm{mL})$

*Corresponding Author. Mailing address: Universidade de Franca - Núcleo de Pesquisa em Ciências Exatas e Tecnológicas - Avenida Dr. Armando de Sales Oliveira, 201- 14404-600- Franca - SP- Brasil. Tel.: (16) 3711-8871 ou (16) 3711-8878. E-mail: mlasilva@unifran.br 
dissolved in DMSO and placed on the inoculated plates. The plates were incubated at $35^{\circ} \mathrm{C}$ for 18 hours. Discs impregnated with DMSO were used as negative control. Amicacine $(30 \mu \mathrm{g})$, penicilin $\mathrm{G}(10 \mathrm{U})$, tetracycline $(30 \mu \mathrm{g})$, polymyxin $\mathrm{B}(300 \mathrm{U})$, vancomycin $(30 \mu \mathrm{g})$ and miconazole $(50 \mu \mathrm{g})$ discs were used as positive controls. Microbial growth inhibition was determined as the diameter of the inhibition zones around the discs. All tests were performed in triplicate.

The Minimum Inhibitory Concentration (MIC) values of the crude hydroalcoholic extract were determined in triplicate by using the microdilution broth method (1) in 96-well microplates. The crude hydroalcoholic extract was dissolved in DMSO $(1 \mathrm{mg} / \mathrm{mL})$, and then diluted in tryptone soya broth to achieve concentrations ranging from 300 to $20 \mu \mathrm{g} / \mathrm{mL}$. The final concentration of DMSO was 10\% (v/v) and this solution was used as negative control. The inoculum was adjusted to each organism to yield a cell concentration of $10^{8} \mathrm{CFU} / \mathrm{mL}$. One well was used as control of the growth of the microorganisms in the medium, and one uninoculated well, free of antimicrobial agent was used to assure the sterility of the medium. Standard antibiotics were used as positive controls. Two-fold serial dilutions of each standard antibiotic were made in tryptone soya broth to achieve concentrations ranging from 5.9 to $0.01 \mu \mathrm{g} / \mathrm{mL}$ (1). The microplates were incubated at $37^{\circ} \mathrm{C}$ for 24 hours, and $40 \mu \mathrm{L}$ of 2,3,5- triphenyltetrazolium chloride $(0.7 \%)$ in aqueous solution and $30 \mu \mathrm{L}$ of resazurin $(0.01 \%)$ were added to indicate the viability of bacteria and yeasts, respectively $(8,13)$. The MIC values were determined as the lowest concentrations of the extract capable of inhibiting microorganisms' growth.

The results of the antimicrobial activity of the hydroalcoholic extract, assayed in vitro by the agar diffusion method, are shown in Table 1. The Syzygium cumini leaves hydroalcoholic extract displayed the highest level of activity against Candida krusei. The inhibition zones varied between $8.3 \pm 0.3 \mathrm{~mm}$ and $14.7 \pm 0.3$ $\mathrm{mm}$. Activity was also detected against a multi-resistant strain of Staphylococcus aureus. The MIC values confirmed the significant activity against the tested microorganisms, as shown in Table 2. The MIC values ranged from 70 to $200 \mu \mathrm{g} / \mathrm{mL}$. Overall, Candida krusei, both multi-resistant and standard strains of Pseudomonas aeruginosa, Candida albicans and Neisseria gonorrhoeae were the most susceptible to this extract, displaying MIC values from 70 to $90 \mu \mathrm{g} / \mathrm{mL}$.

Most antimicrobial medicinal plants are more effective against Gram-positive than Gram-negative bacteria $(9,15)$. Antifungal activity is not common in medicinal plants. For example, 23 extracts of 12 Cuban plants, used in traditional medicine failed to inhibit the growth of yeast (11). However, our current findings show a remarkable activity against Gram-negative bacteria and yeasts, including multi-resistant Gram-negative strains. The differences in susceptibility patterns observed with the two methods may be explained by the differences in diffusibility of
Table 1. Antimicrobial activity of Syzygium cumini leaves hydroalcoholic extract evaluated by agar diffusion method.

\begin{tabular}{lcc}
\hline & \multicolumn{2}{c}{ Inhibition zones (mm) } \\
\cline { 2 - 3 } Microorganisms & $\begin{array}{c}\text { Hydroalcoholic } \\
\text { extract }\end{array}$ & $\begin{array}{c}\text { Standard } \\
\text { antibiotics }\end{array}$ \\
\hline Candida albicans & $12 \pm 0.0$ & $20 \pm 0.6^{1}$ \\
Candida krusei & $14.7 \pm 0.3$ & $27.7 \pm 0.3^{1}$ \\
Escherichia coli & 0.0 & $27.3 \pm 0.0^{2}$ \\
Enterococcus faecalis & $9.7 \pm 0.3$ & $19.7 \pm 1.5^{3}$ \\
Klebsiella pneumonia* & 0.0 & $18.0 \pm 0.0^{2}$ \\
Kocuria rhizophila & $8.7 \pm 0.3$ & $58.3 \pm 1.7^{3}$ \\
Neisseria gonorrhoeae & 0.0 & $37.3 \pm 0.3^{4}$ \\
Pseudomonas aeruginosa & $10.0 \pm 0.0$ & $18.3 \pm 0.3^{5}$ \\
Pseudomonas aeruginosa $*$ & 0.0 & $15.7 \pm 0.3^{5}$ \\
Staphylococcus aureus & $9.0 \pm 0.0$ & $49.0 \pm 0.0^{3}$ \\
Staphylococcus aureus & $12.3 \pm 0.3$ & $25.3 \pm 0.3^{6}$ \\
Shigella flexneri & $8.3 \pm 0.3$ & $22.0 \pm 0.0^{2}$ \\
\hline
\end{tabular}

${ }^{1}$ Miconazole; ${ }^{2}$ Amicacin; ${ }^{3}$ Penicilin G; ${ }^{4}$ Tetracycline; ${ }^{5}$ Polymyxin B; ${ }^{6}$ Vancomycin; * Multi-resistant strains; \pm Standard deviation (mean of three assays).

Table 2. Minimum inhibitory concentrations of Syzygium cumini leaves hydroalcoholic extract.

\begin{tabular}{lcc}
\hline & \multicolumn{2}{c}{$\begin{array}{c}\text { Minimum inhibitory } \\
\text { concentrations }(\mu \mathrm{mg} / \mathrm{mL})\end{array}$} \\
\cline { 2 - 3 } Microorganisms & $\begin{array}{c}\text { Hydroalcoholic } \\
\text { extract }\end{array}$ & $\begin{array}{c}\text { Standard } \\
\text { antibiotics }\end{array}$ \\
\hline Candida albicans & 90 & $>5.90^{1}$ \\
Candida krusei & 70 & $2.95^{1}$ \\
Escherichia coli & 200 & $1.48^{2}$ \\
Enterococcus faecalis & 100 & $0.37^{3}$ \\
Klebsiella pneumonia* & 200 & $5.90^{2}$ \\
Kocuria rhizophila & 200 & $0.02^{4}$ \\
Neisseria gonorrhoeae & 90 & $0.74^{5}$ \\
Pseudomonas aeruginosa & 90 & $5.90^{2}$ \\
Pseudomonas aeruginosa* & 80 & $>5.90^{2}$ \\
Staphylococcus aureus & 200 & $0.18^{4}$ \\
Staphylococcus aureus $*$ & 200 & $1.48^{3}$ \\
Shigella flexneri & 200 & $2.95^{2}$ \\
\hline
\end{tabular}

${ }^{1}$ Miconazole; ${ }^{2}$ Imipenem; ${ }^{3}$ Vancomycin; ${ }^{4}$ Penicilin G; ${ }^{5}$ Tetracycline; * Multi-resistant strains.

the extract in agar. The evaluation of extracts by using agar diffusion assays may lead to a false negative result, once the results are influenced by the agar type, salt concentration, incubation temperature, and molecular size of the antimicrobial components (7). The microdilution broth method is 30 times 
more sensitive than the other methods used to screen plant extracts for antimicrobial activity (6).

The antimicrobial activity of the Syzygium cumini leaves hydroalcoholic extract may be due to tannins and other phenolic constituents. Syzygium cumini is known to be very rich in gallic and ellagic acid polyphenol derivatives $(3,10)$. Also, acylated flavonol glycosides, kaempferol, myricetin, and other polyphenols were isolated from Syzygium cumini leaves $(10,19)$.

Tannins are considered nutritionally undesirable because they precipitate proteins, inhibit digestive enzymes and affect the absorption of vitamins and minerals. However, some kinds of tannins can reduce the mutagenicity of a number of mutagens and display anticarcinogenic, antimicrobial and antioxidant activities (4).

The results obtained in this study suggest a potential application of Syzygium cumini for treatment of skin wounds and further investigations should be conducted in order to explore this application. Other medicinal plants containing phenolic compounds, including tannins, as major constituents are used topically for care and repair of skin wounds (5).

The advantage of the use of topical antimicrobials is their ability to deliver high local concentrations of antibiotic irrespective of vascular supply. Further benefits include the absence of adverse systemic effects, and a low incidence of resistance (16).

Antibiotic-resistant bacteria continue to emerge rapidly, constituting a problem of increasing significance in dermatology. Common pathogenic bacteria, such as Staphylococcus aureus and Pseudomonas aeruginosa, which are predominant organisms in both leg ulcers and superficial wounds, showed increased resistance to commonly used antibiotics (20). The potential of Syzygium cumini leaves hydroalcoholic extract against multi-resistant and standard strains of Staphylococcus aureus and Pseudomonas aeruginosa may be explored in order to develop a topic antimicrobial therapy to promote skin wounds healing.

\section{ACKNOWLEDGEMENTS}

The authors are very grateful to the CNPq, Fapesp and Capes for financial support. All experimental procedures complied with the current laws of the state or country where they were performed.

\section{RESUMO}

\section{Atividade antimicrobiana do extrato das folhas de Syzygium cumini (Myrtaceae)}

A atividade antimicrobiana do extrato das folhas de Syzygium cumini (Myrtaceae), conhecido como "jambolão", foi avaliada. $\mathrm{O}$ extrato hidroalcoólico mostrou atividade contra Candida krusei (halo de inibição de $14.7 \pm 0.3 \mathrm{~mm}$ e CIM $=70 \mu \mathrm{g} / \mathrm{mL}$ ) e cepas multiresistentes de Pseudomonas aeruginosa, Klebsiella pneumoniae e Staphylococcus aureus.

Palavras-chave: Atividade antimicrobiana, método de difusão, método de microdiluição, cepas multiresistentes, Syzygium cumini.

\section{REFERENCES}

1. Andrews, J.M. (2001). Determination of minimum inhibitory concentrations. J. Antimicrob. Chemother., 48, 5-16.

2. Bhandary, M.J.; Chandrashekar, K.R.; Kaveriappa, K.M. (1995). Medical ethnobotany of the siddis of Uttara Kannada district, Karnataka, India. J. Ethnopharmacol., 47, 149-158.

3. Chattopadhyay, D.; Sinha, B.K.; Vaid, L.K. (1998). Antibacterial activity of Syzygium species. Fitoterapia, 69, 356-367.

4. Chung, K.T.; Wei, C.I.; Johnson, M.G. (1998). Are tannins a doubleedged sword in biology and health? Trends Food Sci. Technol., 9, $168-175$

5. Dweck, A.C. (2002). Herbal medicine for the skin. Their chemistry and effects on skin and mucous membranes. Personal Care Mag., 3, 19-21.

6. Eloff, J.N. (1998). A sensitive and quick microplate method to determine the minimal inhibitory concentration of plant extracts for bacteria. Planta Med., 64, 711-713.

7. Greenwood, D. (ed.) (1989). Antibiotic sensitivity testing. In: Antimicrobial Chemotherapy. Oxford University, Oxford, p.91-100.

8. Leverone, M.R.; Owen, T.C.; Tieder, F.S.; Stewart, G.J.; Lim, D.U. (1996). Resting-cell dehydrogenase assay measuring a novel water soluble formazan detects catabolic differences among cells. $J$. Microbiol. Methods, 25, 49-55.

9. Lin, J.; Opoku, A.R.; Geheeb-Keller, M.; Hutchings, A.D.; Terblanche, S.E.; Jäger, A.K.; Van Staden, J. (1999). Preliminary screening of some traditional zulu medicinal plants for anti-inflammatory and anti-microbial activities. J. Ethnopharmacol., 68, 267-274.

10. Mahmoud, I.I.; Marzouk, M.S.A.; Moharram, F.A.; El-Gindi, M.R.; Hassan, A.M.K. (2001). Acylated flavonol glycosides from Eugenia jambolana leaves. Phytochemistry, 58, 1239-1244.

11. Marting, M.J.; Betancourt, J.; Alonso-Gonzalez, N.; Jauregui, A. (1996). Screening of some Cuban medicinal plants for antimicrobial activity. J. Ethnopharmacol., 52, 171-174.

12. National Committee for Clinical Laboratory Standards (NCCLS). (2002). Performance standards for antimicrobial susceptibility testing. Twelfth Informational Supplement M100-S12 NCCLS. Wayne.

13. Palomino, J.C.; Martin, A.; Camacho, M.; Guerra, H.; Swings, J.; Portaels, S. (2002). Resazurin microtiter assay plate: simple and inexpensive method for detection of drug resistance in Mycobacterium tuberculosis. Antimicrob. Agents Chemother., 46, 2720-2722.

14. Rahman, A.U.; Zaman, K. (1989). Medicinal plants with hypoglycemic activity. J. Ethnopharmacol., 26, 1-55.

15. Scrinivasan, D.; Nathan, S.; Suresh, T.; Perumalsamy, O. (2001). Antimicrobial activity of certain Indian medicinal plants used in folkloric medicine. J. Ethnopharmacol., 74, 217-220.

16. Spann, C.T.; Tutrone, W.D.; Weinberg, J.M. (2003). Topical antibacterial agents for wound care: a primer. Dermatol. Surg., 29 620-626

17. Teixeira, C.C.; Rava, C.A.; Silva, P.M.; Melchior, R.; Argenta, R.; Anselmi, F.; Almeida, C.R.C.; Fuchs, F.D. (2000). Absence of antihyperglycemic effect of jambolan in experimental and clinical models. J. Etnopharmacol., 71, 343-347. 
18. Teixeira, C.C.; Pinto, L.P.; Kessler, F.H.P.; Knijnik, L.; Pinto, C.P.; Gastaldo, G.J.; Fuchs, F.D. (1997). The effect of Syzygium cumini (L.) Skeels on post-prandial blood glucose levels in non-diabetic rats and rats with streptozotocin-induced diabetes mellitus. $J$. Ethnopharmacol., 56, 209-213.

19. Timbola, A.K.; Szpoganicz, B.; Branco, A.; Monache, F.D.; Pizzolatti, M.G. (2002). A new flavonol from leaves of Eugenia jambolana. Fitoterapia, 73, 174-176.
20. Valencia, I.C.; Kirsner, R.S.; Kerdel, F.A. (2004). Microbiologic evaluation of skin wounds: alarming trend toward antibiotic resistance in an inpatient dermatology service during a 10 -year period. $J$. Am. Acad. Dermatol., 50, 845-849.

21. Warrier, P.K.; Nambiar, V.P.K.; Ramankutty, C. (1996). Indian Medicinal Plants. Orient Longman Ltd., Hyderabad, p.225-228. 